\title{
Morphometric analysis of External Occipital Crest
}

\author{
Sundar. $\mathrm{R}^{1}$ and Yuvaraj Babu $\mathrm{K}^{2 *}$ \\ ${ }^{1}$ Saveetha Dental College and Hospitals, Saveetha Institute of Medical \\ and Technical Sciences, Saveetha University, Chennai - 600077 India \\ ${ }^{2}$ Assistant Professor, Department of Anatomy, Saveetha Dental College and Hospitals, Saveetha \\ Institute of Medical and Technical Sciences, Saveetha University, Chennai - 600077 India
}

\section{ABSTRACT}

The external occipital crest is a part of the external surface of the squamous part of Occipital bone, it is otherwise called the median nuchal line. It extends from external occipital protuberance to foramen magnum. The inferior nuchal line starts laterally from the middle of crest between the posterior rim of foramen magnum and external occipital protuberance. The main aim of this study is to measure the distance of external occipital crest and position of starting point of inferior nuchal line from the posterior rim of foramen magnum and external occipital protuberance.48 unsexed human skulls were taken from the Department of Anatomy, Saveetha Dental College and hospitals and the distance along external occipital crest between
a. External occipital protuberance to posterior rim of foramen magnum (AC)
b. External occipital protuberance to the inferior nuchal line $(\mathrm{AB})$ and
c. Inferior nuchal line to the posterior rim of foramen magnum (BC)

was measured using the digital Vernier caliper all data were recorded and analyzed statistically. The average mean distance of the measurements taken in 48 skulls between the external occipital protuberance to posterior rim of foramen magnum (AC) was $38.23 \pm 5.28 \mathrm{~mm}$, between external occipital protuberance to the inferior nuchal line (AB) was $19.55 \pm 3.93 \mathrm{~mm}$ and between the inferior nuchal line to the rim of foramen magnum (BC) was $16.63 \pm 2.28 \mathrm{~mm}$ respectively.Our research provides morphometric data of external occipital crest of occipital bone which could be a valuable for surgeons to plan for the cranial base surgeries.

KEY WORDS: OCCIPITAL BONE, EXTERNAL OCCIPITAL CREST , EXTERNAL OCCIPITAL PROTUBERANCE, INFERIOR NUCHAL LINE, POSTERIOR RIM OF FORAMEN MAGNUM.

\section{ARTICLE INFORMATION}

*Corresponding Author: yuvarajbabu@saveetha.com

Received 25th July 2020 Accepted after revision 24th Sep 2020

Print ISSN: 0974-6455 Online ISSN: 2321-4007 CODEN: BBRCBA

Thomson Reuters ISI Web of Science Clarivate Analytics USA and Crossref Indexed Journal

\section{Clarivate
Analytics}

NAAS Journal Score 2020 (4.31) SJIF: 2020 (7.728)

A Society of Science and Nature Publication,

Bhopal India 2020. All rights reserved.

Online Contents Available at: http//www.bbrc.in/

Doi: http://dx.doi.org/10.21786/bbrc/13.8/101 


\section{INTRODUCTION}

External occipital crest is seen in the external surface of the squamous part of the occipital bone. It begins at external occipital protuberance and moves downwards to the foramen magnum. It is convex in shape and present in the middle between the summit of the bone and foramen magnum. External occipital crest is also known as median nuchal line. It provides the attachment to the nuchal ligament. Inferior nuchal line is present in the posterior surface of occipital bone it is the ridge extending laterally from either side of the middle of the external occipital protuberance and foramen magnum, curving slightly upward. Superior nuchal lines have very less chance of damage of intracranial venous penetration(Zipnick et al., 1996). Some cases the external occipital protuberance shows hyperostosis which gives horn-like curved appearance to the external occipital bone(Satyarthee, 2019). In laboratory study of CSM Medical university they have found that most of the skulls have shown exostosis from the external occipital protuberance(Singh, 2012).

The enlargement of external occipital protuberance was found in the young individuals of ancient times; this same growth is now found in CT scan of present generation youngsters (Jacques et al., 2020). Previous research was done on the occipital bone, is helpful in the sexual dimorphism in the archaeological population(Hoover, 2017). Other research was done based on the occipital bone thickness, which was an cadaveric ('Occipital bone thickness: Implications on occipital-cervical fusion. A cadaveric study', 2016). This study helps to know the variation between the thickness of occipital bone of male and female (Zipnick et al., 1996). Other few research was done based on the morphometric and radiologic anatomy of the occipital bone (Naderi et al., 2001).

With a rich case bank established over 3 decades we have been able to publish extensively in our domain (Abdul Wahab et al., 2017; Eapen, Baig and Avinash, 2017; Patil et al., 2017; Jain and Nazar, 2018; J et al., 2018; Marimuthu et al., 2018; Wahab et al., 2018; Abhinav et al., 2019; Ramadorai, Ravi and Narayanan, 2019; Senthil Kumar et al., 2019; Sweta, Abhinav and Ramesh, 2019). Over the past years various research done by our team was on Osteology (Choudhari and Thenmozhi, 2016) (Hafeez and Thenmozhi, 2016)(Kannan and Thenmozhi, 2016)(Keerthana and Thenmozhi, 2016) (Pratha, Ashwatha Pratha and Thenmozhi, 2016) (Nandhini et al., 2018)(Subashri and Thenmozhi, 2016), stature estimation (Krishna, Nivesh Krishna and Yuvaraj Babu, 2016), uses and ill effects of electronic gadgets (Sriram, Thenmozhi and Yuvaraj, 2015) (Thejeswar and Thenmozhi, 2015), on RNA (Johnson et al., 2020) (Sekar et al., 2019), animal studies (Seppan et al., 2018) and in few other fields (Menon and Thenmozhi, 2016)(Samuel and Thenmozhi, 2015). There is a lack of much information on the current topic of morphometric analysis of External Occipital Crest. The main aim of the study is Morphometric analysis of External Occipital Crest.

\section{MATERIAL AND METHODS}

Forty-eight unsexed dry human skulls were taken from the Department of Anatomy of Saveetha Dental College and Hospitals the distance between

1. Lower end of external occipital protuberance to posterior rim of foramen magnum.[AC]

2. External occipital protuberance to inferior nuchal line . $[\mathrm{AB}]$

3. Inferior nuchal line to posterior rim of the foramen magnum .[BC]

were measured using a digital vernier caliper each skull was studied separately for the above measurements were recorded. All data were collected and analyzed statically and the mean $((\mathrm{mm})$ and range $(\mathrm{mm})$ were tabulated separately for understanding purposes [Table 1$\}$.

Figure 1: Picture showing anatomical landmarks used to measure the external occipital crest, A - External occipital protuberance, B- Inferior nuchal line, $\mathrm{C}$ - posterior margin of Foramen Magnum

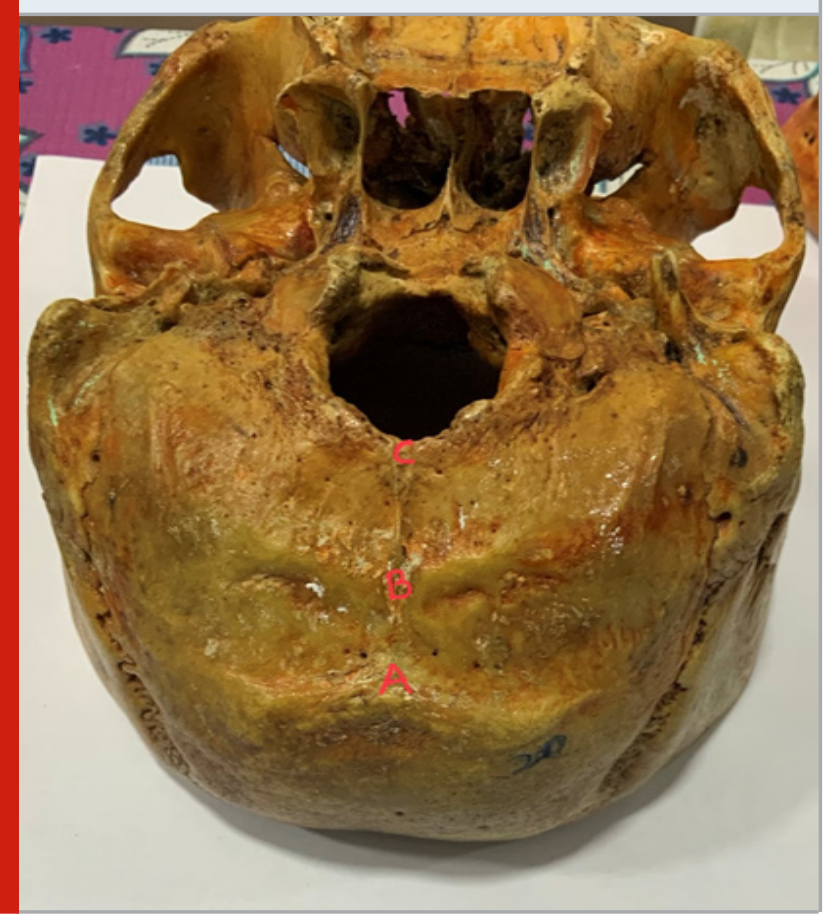

\section{RESULTS AND DISCUSSION}

The measurements from lower end of external occipital protuberance to posterior rim of foramen magnum [AC] was in the range is 25.71 to $50.53 \mathrm{~mm}$ and its mean was measured to be $38.23 \pm 5.28 \mathrm{~mm}$, The distance between the external occipital protuberance to inferior nuchal line $[\mathrm{AB}$ ] was within range of 10.09 to $28.45 \mathrm{~mm}$ and the mean was $19.55 \pm 3.39 \mathrm{~mm}$ finally the distance between the inferior nuchal line to posterior rim of the foramen magnum [BC] was in range of 12.23 to $20.64 \mathrm{~mm}$ and mean value is $16.63 \pm 2.28 \mathrm{~mm}$.from our study we found that these distance varies from individual to individual. 
The external occipital protuberance for determination sex in turkish population (Gülekon and Turgut, 2003). The study found enthesophytes in the occipital protuberance in $41 \%$ of their skull (David Shahar, 2016). We are not able to find any published research done on morphometric measurement of external occipital crest, it was found to be $(38.28 \pm 5.28 \mathrm{~mm})$ and inferior nuchal line at a distance $(19.55 \pm 3.39) \mathrm{mm}$ from external occipital protuberance and $(16.63 \pm 2.28) \mathrm{mm}$ from the posterior border of foramen magnum. From the search of previous research articles we found articles for the surgical applications for nuchal ligament (Kadri and Al-Mefty, 2007). Pain in the external occipital protuberance due to the exostosis (Marshall, Abela and Eccles, 2015) A non metric study was done among the Korean population by using external occipital protuberance for the determination of human gender (Kim and Han, 2015). Nuchal line can be helpful for the dissecting superficial muscle and deep muscle such as muscles of the suboccipital triangle (Campero et al., 2018), but we couldn't find any article related to the external occipital crest.

Table 1. Range and Mean distance in millimeter of various measurements

\begin{tabular}{|l|c|c|}
\hline $\begin{array}{l}\text { Distance } \\
\text { between }\end{array}$ & $\begin{array}{c}\text { Range } \\
\text { in } \mathrm{mm}\end{array}$ & $\begin{array}{c}\text { Mean Distance } \\
\text { in mm }\end{array}$ \\
\hline $\begin{array}{l}\text { External occipital } \\
\text { protuberance to } \\
\text { posterior rim of } \\
\text { foramen magnum (AC) }\end{array}$ & $25.71-50.53$ & $38.23 \pm 5.28$ \\
\hline $\begin{array}{l}\text { External occipital } \\
\text { protuberance } \\
\text { to the inferior } \\
\text { nuchal line (AB) }\end{array}$ & $10.09-28.45$ & $19.55 \pm 3.93$ \\
\hline $\begin{array}{l}\text { Inferior nuchal line to the } \\
\text { posterior rim of foramen } \\
\text { magnum (BC) }\end{array}$ & $12.23-20.64$ & $16.63 \pm 2.28$ \\
\hline
\end{tabular}

\section{CONCLUSION}

Since most of the research have only done on the external occipital protuberance and occipital cervical fusion of the bone, but in our study we have collected the measurement data for the external occipital crest and this data would be helpful for the neurosurgeons to plan for the cranial based surgeries.

\section{ACKNOWLEDGEMENTS}

We acknowledge Department of Anatomy for allowing us to use bones from their collection for this study

Conflict of Interest: The author declares that there is no conflict of interest in the present study.

\section{REFERENCES}

Abdul Wahab, P. U. et al. (2017) 'Risk Factors for Postoperative Infection Following Single Piece Osteotomy’,
Journal of maxillofacial and oral surgery, 16(3), pp. 328-332.

Abhinav, R. P. et al. (2019) 'The Patterns and Etiology of Maxillofacial Trauma in South India', Annals of maxillofacial surgery, 9(1), pp. 114-117.

Campero, A. et al. (2018) 'The Nuchal Lines as Anatomic Landmarks to Dissect the Muscles in the Far Lateral Approach', World neurosurgery. World Neurosurg, 113. doi: 10.1016/j.wneu.2018.02.090.

Choudhari, S. and Thenmozhi, M. S. (2016) 'Occurrence and Importance of Posterior Condylar Foramen', Research Journal of Pharmacy and Technology, p. 1083. doi: 10.5958/0974-360x.2016.00206.7.

David Shahar, M. G. L. S. (2016) 'A morphological adaptation? The prevalence of enlarged external occipital protuberance in young adults', Journal of anatomy. Wiley-Blackwell, 229(2), p. 286.

Eapen, B. V., Baig, M. F. and Avinash, S. (2017) 'An Assessment of the Incidence of Prolonged Postoperative Bleeding After Dental Extraction Among Patients on Uninterrupted Low Dose Aspirin Therapy and to Evaluate the Need to Stop Such Medication Prior to Dental Extractions', Journal of maxillofacial and oral surgery, 16(1), pp. 48-52.

Gülekon, I. N. and Turgut, H. B. (2003) 'The external occipital protuberance: can it be used as a criterion in the determination of sex?', Journal of forensic sciences, 48(3), pp. 513-516.

Hafeez, N. and Thenmozhi (2016) 'Accessory foramen in the middle cranial fossa', Research Journal of Pharmacy and Technology, p. 1880. doi: 10.5958/0974360x.2016.00385.1.

Hoover, K. C. (2017) 'Human occipital bone sexual dimorphism in an Archiac period archaeological population', bioRxiv. doi: 10.1101/177758.

Jacques, T. et al. (2020) 'Enlarged External Occipital Protuberance in young French individuals' head CT: stability in prevalence, size and type between 2011 and 2019', Scientific reports. Nature Publishing Group, 10(1), pp. 1-9.

Jain, M. and Nazar, N. (2018) 'Comparative Evaluation of the Efficacy of Intraligamentary and Supraperiosteal Injections in the Extraction of Maxillary Teeth: A Randomized Controlled Clinical Trial', The journal of contemporary dental practice, 19(9), pp. 1117-1121. Johnson, J. et al. (2020) 'Computational identification of MiRNA-7110 from pulmonary arterial hypertension (PAH) ESTs: a new microRNA that links diabetes and PAH', Hypertension research: official journal of the Japanese Society of Hypertension, 43(4), pp. 360362.

J, P. C. et al. (2018) 'Prevalence and measurement of anterior loop of the mandibular canal using CBCT: A cross sectional study', Clinical implant dentistry and related research, 20(4), pp. 531-534.

Kadri, P. A. S. and Al-Mefty, 0. (2007) 'Anatomy of the Nuchal Ligament and Its Surgical Applications', 
Operative Neurosurgery, pp. ONS301-ONS304. doi: 10.1227/01.neu.0000303985.65117.ea.

Kannan, R. and Thenmozhi, M. S. (2016) 'Morphometric Study of Styloid Process and its Clinical Importance on Eagle's Syndrome', Research Journal of Pharmacy and Technology, p. 1137. doi: 10.5958/0974360x.2016.00216.x.

Keerthana, B. and Thenmozhi, M. S. (2016) 'Occurrence of foramen of huschke and its clinical significance', Research Journal of Pharmacy and Technology, p. 1835. doi: 10.5958/0974-360x.2016.00373.5.

Krishna, R. N., Nivesh Krishna, R. and Yuvaraj Babu, K. (2016) 'Estimation of stature from physiognomic facial length and morphological facial length', Research Journal of Pharmacy and Technology, p. 2071. doi: 10.5958/0974-360x.2016.00423.6.

Marimuthu, M. et al. (2018) 'Canonical Wnt pathway gene expression and their clinical correlation in oral squamous cell carcinoma', Indian journal of dental research: official publication of Indian Society for Dental Research, 29(3), pp. 291-297.

Marshall, R. C., Abela, C. and Eccles, S. (2015) 'Painful exostosis of the external occipital protuberance', Journal of Plastic, Reconstructive \&t Aesthetic Surgery, pp. e174-e176. doi: 10.1016/j.bjps.2015.06.013.

Menon, A. and Thenmozhi, M. S. (2016) 'Correlation between thyroid function and obesity', Research Journal of Pharmacy and Technology, p. 1568. doi: 10.5958/0974-360x.2016.00307.3.

Naderi, S. et al. (2001) 'Morphologic and Radiologic Anatomy of the Occipital Bone', Journal of spinal disorders. J Spinal Disord, 14(6). doi: 10.1097/00002517200112000-00006.

Nandhini, J. S. T. et al. (2018) 'Size, Shape, Prominence and Localization of Gerdy's Tubercle in Dry Human Tibial Bones', Research Journal of Pharmacy and Technology, p. 3604. doi: 10.5958/0974-360x.2018.00663.7.

Occipital bone thickness: Implications on occipitalcervical fusion. A cadaveric study' (2016) Acta orthopaedica et traumatologica turcica. No longer published by Elsevier, 50(6), pp. 606-609.

Patil, S. B. et al. (2017) 'Comparison of Extended Nasolabial Flap Versus Buccal Fat Pad Graft in the Surgical Management of Oral Submucous Fibrosis: A Prospective Pilot Study', Journal of maxillofacial and oral surgery, 16(3), pp. 312-321.

Pratha, A. A., Ashwatha Pratha, A. and Thenmozhi, M. S. (2016) 'A Study of Occurrence and Morphometric Analysis on Meningo Orbital Foramen', Research Journal of Pharmacy and Technology, p. 880. doi: 10.5958/0974-360x.2016.00167.0.

Ramadorai, A., Ravi, P. and Narayanan, V. (2019) 'Rhinocerebral Mucormycosis: A Prospective Analysis of an Effective Treatment Protocol', Annals of maxillofacial surgery, 9(1), pp. 192-196.

Samuel, A. R. and Thenmozhi, M. S. (2015) 'Study of impaired vision due to Amblyopia', Research Journal of Pharmacy and Technology, p. 912. doi: 10.5958/0974360x.2015.00149.3.

Satyarthee, G. D. (2019) ‘External Occipital Protuberance Projecting as Downward Curved Horn Presenting with Intractable Occipital Pain: Report of a First Case', Journal of pediatric neurosciences. Wolters Kluwer -Medknow Publications, 14(3), p. 173.

Sekar, D. et al. (2019) 'Methylation-dependent circulating microRNA 510 in preeclampsia patients', Hypertension Research, pp. 1647-1648. doi: 10.1038/ s41440-019-0269-8.

Senthil Kumar, M. S. et al. (2019) 'Inflammatory pseudotumour of the maxillary sinus: clinicopathological report', Oral Surgery, 12(3), pp. 255-259.

Seppan, P. et al. (2018) 'Therapeutic potential of Mucuna pruriens (Linn.) on ageing induced damage in dorsal nerve of the penis and its implication on erectile function: an experimental study using albino rats', The Aging Male, pp. 1-14. doi: 10.1080/13685538.2018.1439005.

Singh, R. (2012) 'Bony Tubercle at External Occipital Protuberance and Prominent Ridges', The Journal of craniofacial surgery. J Craniofac Surg, 23(6). doi: 10.1097/SCS.0b013e31826c7d48.

Sriram, N., Thenmozhi and Yuvaraj, S. (2015) 'Effects of Mobile Phone Radiation on Brain: A questionnaire based study', Research Journal of Pharmacy and Technology, p. 867. doi: 10.5958/0974-360x.2015.00142.0.

Subashri, A. and Thenmozhi, M. S. (2016) 'Occipital Emissary Foramina in Human Adult Skull and Their Clinical Implications', Research Journal of Pharmacy and Technology, p. 716. doi: 10.5958/0974360x.2016.00135.9.

Sweta, V. R., Abhinav, R. P. and Ramesh, A. (2019) 'Role of Virtual Reality in Pain Perception of Patients Following the Administration of Local Anesthesia', Annals of maxillofacial surgery, 9(1), pp. 110-113.

Thejeswar, E. P. and Thenmozhi, M. S. (2015) 'Educational Research-iPad System vs Textbook System', Research Journal of Pharmacy and Technology, p. 1158. doi: 10.5958/0974-360x.2015.00208.5.

Wahab, P. U. A. et al. (2018) 'Scalpel Versus Diathermy in Wound Healing After Mucosal Incisions: A SplitMouth Study', Journal of oral and maxillofacial surgery: official journal of the American Association of Oral and Maxillofacial Surgeons, 76(6), pp. 1160-1164.

Zipnick, R. I. et al. (1996) 'Occipital Morphology. An Anatomic Guide to Internal Fixation', Spine. Spine (Phila Pa 1976), 21(15). doi: 10.1097/00007632199608010-00001. 